\title{
KEY ASPECTS OF CASH MANAGEMENT IN THE COMPANY'S BUSINESS
}

\author{
Lidija Barjaktarović1 ${ }^{1}$ Marko Milojević ${ }^{1}$, Brankica Trajković ${ }^{2}$ \\ ${ }^{1}$ Faculty of Business in Belgrade, Singidunum University, Belgrade, Serbia \\ ${ }^{2}$ Grand Casino d.o.o., Belgrade, Serbia
}

\section{Key words:}

cash,

investment,

investment alternative,

capital profit,

financial result.

\begin{abstract}
Cash management is essential part of efficient company's business and it can be used as criteria for king success of Chief Financial Officers. In multinational companies, it is expected that financi Accordingly, domestic competent public is interested in way how cash management can improve performances of one company. Moreover, it is important to know available investment alternatives, planned investments and maintenance, regulation in company's basic industry and other industries applicable on own business, and tax treatment of various basis of payment. Optimal financial result can be achieved thanks to good allocation of available funds, thanks to determine the priorities in payments and achieving tax deduction. It is very important to consider accounting aspect of particular financial decision, before the decision of cash disbursement is made. In this research, authors will present way of cash management in Grand Casino Belgrade in period of 2009 to 2013, on the basis of available official financial and auditor reports on the company's site.
\end{abstract}

This research paper was part of the research project “Advancing Serbia's Competitiveness in the Process of EU Accession”, No. 47028, during the period 2011-2015, financed by the Serbian Ministry of Science and Technological Development.

\section{INTRODUCTION}

Grand Casino doo Beograd was founded in 2005 (jointly owned by the Serbian State Lottery Company (10\%) and a foreign partner (90\%)), when it was granted a ten-year license as the first and only casino operator in Belgrade. Its core business activity is organising games of chance and food and beverage service (four restaurants owned by the company). The company opened for business in 2008 due to delay in the renovation of the Yugoslavia Hotel (company's premises are located within the hotel building). In 2009, it witnessed change of ownership on the side of the foreign partner (currently owned by a Greek operator). [4] Company now faces many problems, particularly: collection of receivables, (ill-) liquidity, frequent changes of law regulations, dramatic differences in tax treatment of different payments, exchange rate fluctuations, decreasing purchasing power of service users, etc. According to the regulations in forces in the Republic of Serbia applicable to domestic banks, companies are financed solely through owner's capital. Accordingly, the following challenges present themselves before the chief financial officer: smart budgeting, optimal cash management, knowledge of capital requirements and the need for investments. [3]

The subject of this paper is to define key aspects of cash management in unpredictable modern setting. The purpose of this paper is to point out activities which the CFO (Chief Financial Officer) must perform to ensure better company performance. The basic hypothesis of this document is that optimal cash management can be pursued. In order to prove this hypothesis, the authors will use the financial statements of Grand Casino doo Beograd for the period between 2009 and 2013, publicly available on the web site of the Serbian Business Registers Agency. [4, 5, 6, 7]

\section{KEY PERFORMANCE INDICATORS DEMONSTRATING SUCCESSFUL BUSINESS OPERATIONS OF GRAND CASINO DOO BEOGRAD}

Owners of Grand Casino have invested $€ 90$ million in its business, both initially, for the construction and renovation of the building and for the procurement of necessary equipment which is in use 24 hours a day. This was a lot more than the originally projected investment of $€ 45$ million which was the consequence of wrong assessments and delays in the renovation of the Yugoslavia Hotel and the effects of global economic crisis, which set back the internal rate of return from standard 7 to 15 years or more. [3] Also, the company is allowed to perform its core activities only if in possession of the license issued by the competent state authorities whereas the very nature of this business requires certain investment in maintenance, equipment replacement and refurbishment of the business premises and furniture [3].

By looking at the main balance sheet items of Grand Casino (Table 1 in the Appendix), it is easy to note that it is classified as a large company based on the generated income and assets in its possession. Taking into account previous arguments and the problem of indolence of minority shareholders, one should not be surprised that the company's income statement continuously shows expenses exceeding income. When analysing the balance sheet positions, one thing becomes evident: fixed assets are shirting every year. The cause for this lies in specific economic activity of Grand Casino since considerable portion of its fixed assets is composed of equipment with relatively short economic life, and therefore, its write-off leads to diminished aggregate value of fixed assets. Insufficient investment activities reflected in reduced aggregate value of fixed assets result from disagreement between the shareholders regarding the amounts 
to be invested and its dynamics which, in the long run, may jeopardise company's market position.

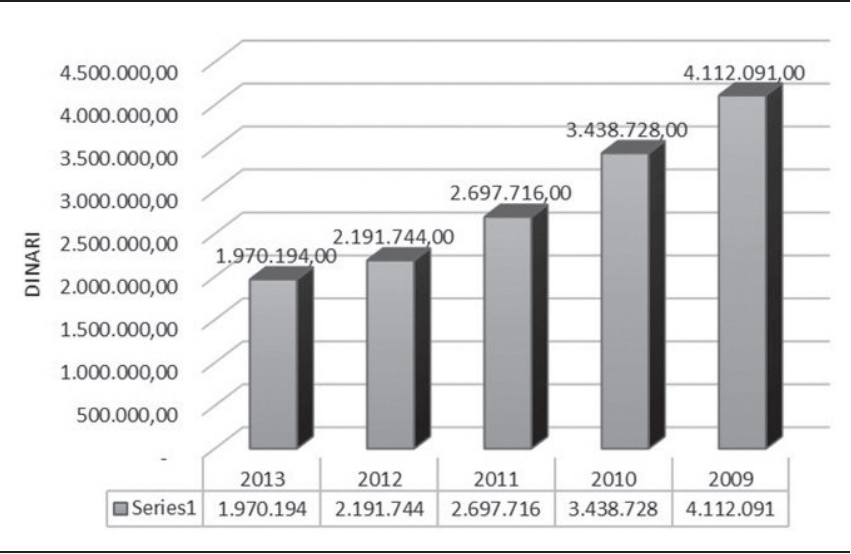

Figure 1: Fixed Assets Movement in the Period from 2009 to 2013 (in thousands of dinars)

[Source: calculated by authors]

Despite the fact that fixed assets have been recording a downward trend over the years, working assets are on the rise which is to be expected considering the specific nature of activity, and is in line with other companies which are classified as large companies pursuant to domestic accounting legislation. [8] Unlike its balance in 2009, the first year of the analysis, working assets item recorded a $118.43 \%$ increase in 2013 . The movement of the working assets item is interesting. Inventory and receivables have recorded the opposite trend, whereas short-term financial assets have recorded the same upward movement as the working assets. This data and the fact that the proportionately largest amounts were invested in these items are precisely the reasons why we chose to focus our research on the short-term assets and cash management.

Trend of current assets

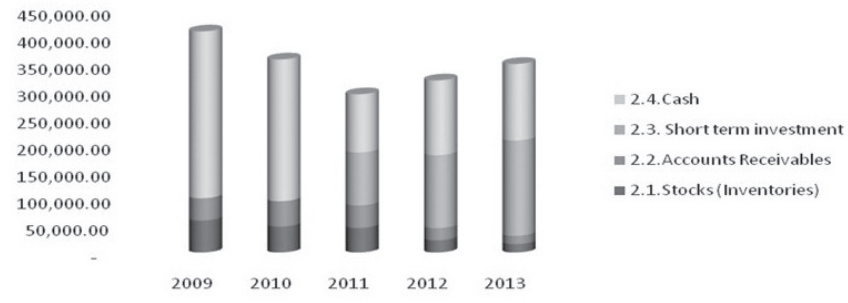

Figure 2: Movement of Current Assets in the Period from 2009 to 2013 (in thousands of dinars)

[Source: calculated by authors]

Within the period under observation, the increase in longterm funding of working assets is also evident, which is favourable for financial stability of Grand Casino. The amount of capital is fixed, though there is a problem with recapitalisation on the part of the domestic co-owner.

In 2011, visible changes have been implemented in the company's financial policy, primarily in respect of cash management methodology and placement of surplus monetary assets into investment units of existing cash funds operating in the Republic of Serbia (balance sheet item: short-term financial assets). Furthermore, it has to be pointed out that the company is exposed to exchange rate risk (exchange rate for Euro in the period from 2009 to 2013 went up from 85 to 115 dinars), which is reflected in the balance sheet items such as equity, fixed assets and long-term liabilities.

\section{KEY ASPECTS OF CASH MANAGEMENT}

Key aspects of cash management in the business operations of Grand Casino are as follows: smart budgeting for the next five years (income, expenses, CAPEX/Capital Expenditures), 2) optimal cash management (on a daily, monthly, annual and fiveyear basis), 3) knowledge of capital requirements (reinvestment in one's own assets or utilisation of external financial sources such as loans, operating / financial leases or borrowings from the founder), and 4) objectivity in the decision making process regarding capital investments (with the aim of achieving maximum return on investment). This implies introducing changes to the daily (operational) level of business activities. [3]

Smart budgeting implies cost reduction, good knowledge of law regulations applicable to the core business activities of the company, as well as those applicable to its secondary activities, but also obtaining official opinions from relevant state authorities regarding the introduction of practices used in other areas of economy and other business activities. In addition to that, a correlation between the financing and operating activities of the company must be in place. It is very important that the CFO understands the core business activity of the company but also that organisational units of the company understand their own role in achieving financial goals. Accordingly, objectivity is highly necessary in evaluating the extent to which the operating costs may be reduced without negative effects on business results and service quality. Likewise, it is important to ensure that available human resources are used properly or that necessary changes are made in order to improve the completion of company's daily business operations. And, naturally, it is vital to have a CFO who is ready to obtain, from relevant state authorities, opinions which may be implemented in company's core activities and which can serve to expand the business operations and reduce tax liabilities. In line with this, Grand Casino obtained the opinion of the competent ministry according to which certain associated costs are positive since they increase the primary income such as: 1) food and beverage consumption (a direct cost of production of company's own products in 4 restaurants) offered to players who are thus stimulated to stay longer and spend more money on the games of chance. From the financial aspect, it means that investment in company's own products for the purpose of stimulating business growth is not subject to calculation and payment of value added tax; 2) gifts to internal group of clients, in this case, the players, are tax deductible since they are given to promote business performance... [3]. Insight into Grand Casino's income statement (Table 2, Appendix) reveals that the operating income is relatively stable and that operating expenses are reduced and business results improved. Also, there is a gradual decrease in the non-standard results.

Grand Casino achieved double benefits on the basis of its bookkeeping method (as presented). The first is reflected in the fact that operating expenses are reduced. In 2013, operating income increased by $3,600,000$ RSD which, due to being recognized within account 530 , instead of 551 , reduced the costs in the amount of $\mathrm{VAT}^{1}$, whereas operating income was stable. On the other hand, this increased the company's liquidity by $3,600,000$ RSD on an annual level as a result of the fact that company had, on an average, 300,000 RSD less to pay for taxes. Based on this bookkeeping method we can see how innovation and deep knowledge of accounting theory can be beneficial for the company for the purpose of:

1 Charging the cost to account 551 Represenation costs prevents the company from recognizing incoming VAT, therefore the entire amount is charged to expenses. Charging the account 530 for costs of services incurred to provide such services enables the account to be divided into supplier account 433 and incoming VAT account 270 


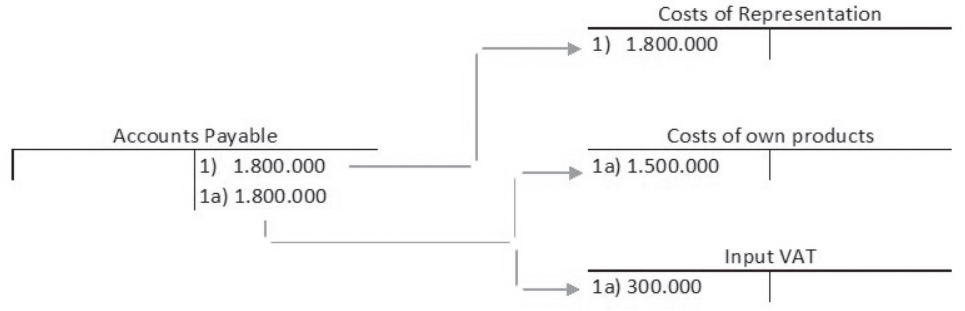

Figure 3: How Putting Theory into Practice Helped Improve Business Results of Grand Casino - Overview

[Source: Authors]

This is a simpliefied form of bookkeeping and does not show the reception of material and internal use of services (accounts 530 and 621 ). Diagram is presented in order to provide insight on how good knowledge of accounting regulations may improve company performance.

1. Recognizing higher operating income,

2. Increasing monetary assets available on its bank account,

Optimal cash management includes a wide range of activities such as: frequently checking the liquidity of its business partners, improving the terms and conditions of its purchase agreements, accepting adequate security instruments or advance payments, setting credit limits and procedures for blocking buyer's accounts; prolongation of payment deadlines especially for marketing services $\left(20 \%\right.$ by $15^{\text {th }}$ day of the next month, remaining invoiced amount payable in 30 or 60 days), establishing payment priorities (taxes and charges payable to state authorities, utilities, salaries, purchase of material needed for production and maintenance, suppliers - marketing segment), determining payment schedule (twice a month i.e. every Tuesday), ensuring two or more offers available from which to choose when buying certain products (ensures lower prices and better payment conditions), negotiating additional discounts and entering into adequate insurance contracts which provide coverage for the entire amount; reducing the supplies (raw materials and finished goods); reducing cash in treasury for payment purposes and investing surplus amounts in investment units (return is always higher than the reference interest rate set by the National Bank of Serbia); in the meantime, tax laws have changed and tax on capital gains is payable once a year after the tax balance report for the previous year has been submitted which is beneficial for cash movement), etc. Company's core business activity is such that it has negative income which requires additional actions on the part of the CFO to obtain opinion of the competent ministry which would enable the company to pay daily takings to its commercial bank account as a sum of its daily takings and not just positive daily takings as is current practice. It is important to note that the daily takings are not equal to income when it comes to this business activity. [3]
Ongoing maintenance in Grand Casino is defined by the budget. Investment in maintenance is however the responsibility of managers of each organisational unit which means that they are directly responsible for determining the economic lives of fixed assets and for planning (full or partial) additional investments within the company investment plan. The said change in the procedure is the result of good understanding of business and optimisation of company's results.

It can be noted that the measures implemented by the management and CFO resulted in positive cash flow (Table 3 ). Thereby we have proven our initial hypothesis that optimal cash management can be pursued within the business operations of the company.

\section{CONCLUSION}

The research we conducted and presented in this paper proves that optimal cash management may be pursued in business operations of the company. It is important that the CFO maintains wide perspective and openness in facing challenges and to have no fear when it comes to obtaining opinions from relevant state authorities in order to improve business operations of his/her company. Besides, CFO should keep in mind the essence of the business and its long-term plans (budgeting), cash management, capital requirements and to maintain objectivity in decisions regarding capital investments. Finally, it is also important that owners and CEO support the financial director's initiatives and proposals. The paper presents overview and explanation of the procedure involving good knowledge of accounting theory that can enhance company's performance and savings. Correlation of costs and effects is precisely that accounting segment which can both improve business results and provide insight into the chief accountant's and CFO's ap-

\begin{tabular}{lccccc}
\hline \multicolumn{1}{c}{ Item } & 2013 & 2012 & 2011 & 2010 & 2009 \\
\hline Net cash inflow (outflow) from operating activities & 67.022 & 81.962 & $(8.857)$ & $(31.838)$ & $(687.623)$ \\
\hline Net cash inflow (outflow) from investment activities & $(59.550)$ & $(48.066)$ & $(45.877)$ & $(23.912)$ & $(17.458)$ \\
\hline Net cash inflow (outflow) from financing activities & $(4.209)$ & $(3.019)$ & $(100.292)$ & - & $(135.212)$ \\
\hline Total cash inflow & 1.149 .021 & 1.210 .292 & 1.412 .483 & 1.147 .776 & 1.382 .106 \\
\hline Total cash outflow & 1.145 .758 & 1.179 .415 & 1.567 .509 & 1.203 .526 & 1.418 .539 \\
\hline Net cash inflow (outflow) & 3.263 & 30.877 & $(155.026)$ & $(55.750)$ & $(36.433)$ \\
\hline
\end{tabular}

Table 3 Basic indicators taken from Cash Flow Statement of Grand Casino doo Beograd in the period from 2009 to 2013 (in thousands of dinars)

[Source: 4, 5, 6, 7] 
proach to achieving company's primary objective - boosting profit. This paper can set an example of combining theory and practice to companies operating in other fields since implementation of accounting regulations within the applicable legal framework is the reflection of the professional commitment of the chief accountant and chief financial director.

\section{REFERENCES}

[1] Barjaktarović, L. , Jović, Z., Milojević, M., Poslovne finansije, Univerzitet Singidunum, Beograd, 2013
[2] Erste group (2008): “Group Real Estate Policy - Investment”

[3] Trajković, B., Planning in time of uncertainty, Presentation on Controlling Forum, Prague, 2014

[4] Annual report of Grand Casino d.o.o. Beograd for 2010.

[5] Annual report of Grand Casino d.o.o. Beograd for 2011.

[6] Annual report of Grand Casino d.o.o. Beograd for 2012.

[7] Annual report of Grand Casino d.o.o. Beograd for 2013.

[8] Milojević, M. Uticaj stalnih sredstava na poslovanje preduzeća, PhD Thesis, Univerzitet Singidunum, Beograd, 2013

\section{APPENDIX}

\begin{tabular}{|c|c|c|c|c|c|}
\hline Item & 2013 & 2012 & 2011 & 2010 & 2009 \\
\hline FIXED ASSETS & 1.970 .194 & 2.191 .744 & 2.697 .716 & 3.438 .728 & 4.112 .091 \\
\hline WORKING ASSETS & 2.325 .815 & 2.225 .541 & 1.537 .767 & 1.609 .771 & 1.064 .772 \\
\hline Inventory & 15.418 & 22.588 & 45.527 & 47.923 & 59.253 \\
\hline Short-term receivables & 15.490 & 22.616 & 41.758 & 47.273 & 41.382 \\
\hline Short-term financial assets & 177.140 & 135.563 & 98.573 & & \\
\hline Cash & 142.309 & 139.046 & 108.169 & 263.513 & 310.222 \\
\hline CAPITAL LOSS & 4.090 .393 & 3.896 .686 & 3.450 .360 & 3.209 .558 & 2.380 .385 \\
\hline EQUITY & 85.483 & 85.483 & 85.483 & 85.483 & 85.483 \\
\hline Long-term reservations and liabilities & 9.009 .536 & 8.904 .795 & 8.176 .953 & 8.258 .057 & 7.544 .157 \\
\hline Short-term liabilities & 539.098 & 498.471 & 425.419 & 454.765 & 443.586 \\
\hline
\end{tabular}

Table 1. Key Performance Indicators Taken from the Balance Sheet Prepared by Grand Casino doo Beograd in the Period from 2009 to 2013 (in thousands of dinars)

[Source: $4,5,6,7]$

\begin{tabular}{lccccc}
\hline Item & 2013 & 2012 & 2011 & 2010 & 2009 \\
\hline Operating income & 1.030 .594 & 1.028 .823 & 1.102 .982 & 1.276 .518 & 1.197 .825 \\
\hline Operating expenses & 1.271 .865 & 1.572 .342 & 1.885 .150 & 2.121 .468 & 1.806 .016 \\
\hline Operating loss & 241.271 & 543.519 & 782.168 & 844.950 & 608.191 \\
\hline Financial results & 4.755 & $(12.528)$ & 72.514 & $(6.216)$ & 1.655 \\
\hline Non-standard results & 234.332 & 531.499 & 768.744 & 822.795 & 576.803 \\
\hline Net loss & 193.707 & 446.326 & 240.801 & 829.173 & 607.291 \\
\hline
\end{tabular}

Table 2. Key Performance Indicators Taken from the Income Statement Prepared by Grand Casino doo Beograd from 2009 to 2013 (in thousands of dinars)

[Source: $4,5,6,7]$

\section{KLJUČNI ASPEKTI UPRAVLJANJA GOTOVINOM U POSLOVANJU KOMPANIJE}

Lidija Barjaktarović ${ }^{1}$, Marko Milojević1 ${ }^{\text {, Brankica Trajković }}{ }^{3}$

${ }^{1}$ Poslovni fakultet u Beogradu, Univerzitet Singidunum, Danijelova 32, Beograd, Srbija, lbarjaktarovic@singidunum.ac.rs

${ }^{2}$ Poslovni fakultet u Beogradu, Univerzitet Singidunum, Danijelova 32, Beograd, Srbija, mmilojevic@singidunum.ac.rs

${ }^{3}$ Grand Casino d.o.o., Bulevar Nikole Tesle 3, Beograd, Srbija, brankica.trajkovic@grandcasinobeograd.com

\section{Apstrakt:}

Upravljanje gotovinom je neophodni element u efikasnom poslovanju privrednog subjekta i može poslužiti kao kriterijum za rangiranje sposobnosti i uspešnosti finansijskog direktora. U multinacionalnim kompanijama od finansijskog direktora se očekuje da obavlja širok spektar aktivnosti i da poznaje kako domaću tako i stranu računovodstvenu regulativu. Iz ovog razloga u žiži domaće stručne javnosti jeste način na koji upravljanje gotovinom može unaprediti performanse jednog privrednog subjekta. U skladu sa tim vrlo je važno poznavanje dostupnih investicionih alternativa, planiranih investicija i održavanja, zakonskih propisa iz osnovne delatnosti kompanije, ali i korisnih mišljenja koja se primenjuju u drugim privrednim oblastima i delatnostima, kao i poreskih tretmana različitih osnova plaćanja. Optimalan finansijski rezultat može da se ostvari dobrom alokacijom raspoloživih sredstava, utvrđujući prioritete plaćanja i sticanja poreskih umanjenja. Vrlo je važno pre donošenja odluke u kom pravcu će se usmeriti gotovina, računovodstveno proći kroz efekat konkretne finansijske odluke. U ovom radu će biti prikazan način na koji se upravlja gotovinom u preduzeću Grand Casino Beograd u periodu od 2009. do 2013. godine, na osnovu zvaničnih finansijskih i revizorskih izveštaja dostupnih na sajtu Agencije za privredne registre.

\section{Ključne reči:}

\section{gotovina,}

plasman,

investiciona alternativa,

kapitalna dobit,

finansijski rezultat. 